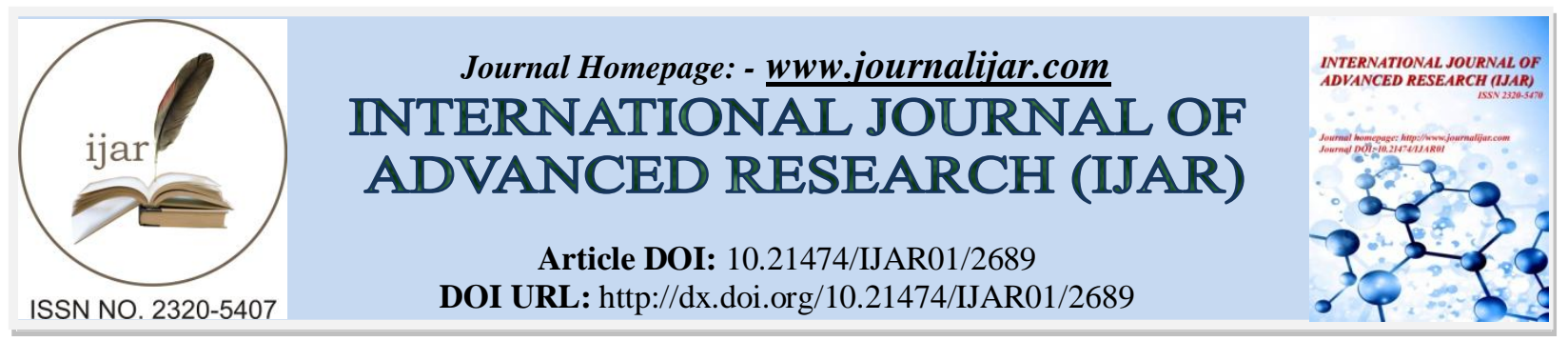

RESEARCH ARTICLE

\title{
SOCIO-ECONOMIC PROBLEM OF AGED PERSON: A STUDY OF ATELI NANGAL MAHENDERGADH.
}

Subhash Sinhmar and Rakesh Kumar.

Research Scholar, Department of Sociology, K.U. K, India.

\section{Manuscript Info}

Manuscript History

Received: 31 October 2016

Final Accepted: 01 December 2016

Published: December 2016

Key words:-

Family, Ageing, Problems, Social

security, Decision making.

\section{Abstract}

The present study is carried out in Mohindergarh district randomly with the help of lottery method. Mohindergarh district has six blocks namely: Narnaul, Mohindergarh, Ateli, Nangal Choudhary, Kanina and Satnali. We randomly selected one block i.e. Ateli for study purpose. In the Ateli block, there are 72 villages. Out of these 72 villages, we randomly selected Ateli Nangal village. The population of the Ateli Nangal is 2235 which includes $700 \mathrm{men}, 540$ women, and 995 children. Village has 335 households. Data have taken from every third household from the list procured from the Panchayat office. Every third household means around 118 households made our sample. Thus, in all interviewed 86 persons who include males and females of the household. The data revealed that out of total 86 respondents, majority of them belonged to man respondents. Regarding age, majority of the respondent belonged to age group between 60-69 years. Most of the respondents were married. Regarding occupation, mostly respondent were engaged in agriculture occupation in the past. Regarding caste, majority of the respondent belonged to Ahir caste. It further analysed that majority of the respondents were illiterate. The problem of the old is their economic position, the reduction or loss of income during old age. Pensions, majority of the respondent were receiving old age pension (63.95 per cent).

Copy Right, IJAR, 2016,. All rights reserved.

\section{Introduction:-}

Family is the basic and universal social institution. Family represents both an institution as well as association (Pandey: 1994). Family is divided into two categories- nuclear family and extended family. Extended family consists of two or more related nuclear families living together in the same place, usually consisting of several generations living together in the same units (Coleman and Gressay: 1986). Elderly in the family enjoyed undisputed authority and power. Aged in the family gets special attention from the women, particularly the daughter-in-law. Older persons have always been in integral and important part of the family in Indian society. Ageing is an emerging phenomenon in the Indian context as it the second most populous country in the world along with improved life expectancy. The reduction in fertility level, reinforced by steady increase in the life expectancy has produced fundamental changes in the age structure of the population, which in turn leads to the aging population. there are 100 million older persons in India today, and the number is growing to grow to 323 million by 2050, with life expectancy having increased from 40 year in 1951, 67.14 year male (66.08), female (68.33 year) 
2013, a person has 27 years more live than be would have 50 years back (India Demographic Profile: 2013). Even where there is co-residing marginalization isolation and insecurity is felt among the older persons due to the generation gap and change in lifestyles. Increase in lifespan also results in chronic functional disabilities. chores as simple as the activities of daily living is creating a need for assistance required by the older persons to manage.

\section{Objective of the study:-}

1. To analyse the socio-economic background of elderly persons.

2. To delineates the social, economic problems of the elderly people.

\section{Review of related Literature:-}

Varmani and Darshan (1999) revealed that major factors affecting the health of the older people were social, economic, psychological and demographic. Health status of older people is influenced by type of family, family status, attitude of family members towards aged. Nayer (2000) the study concluded that the attitude, both professional and general seems to be that the illness was an essential part of old age and most of the illness of the old have no cure but only palliatives. Siva (2002) observed that the various problems are faced by the elderly in our society. Economic problem occupy an important positions Satyanarayana (2002) found that the problem of aging considers very serious, because it leads to the destruction of social protection by the family network. And the health status in care of male is more vulnerable that of female. Rajan (2004) in his study that majority of the elderly are deprived of the basic necessities and are thus in chronic poverty. The majority of the elderly is dependent and even completed to work when too old to earn a living. Pappathi et al. (2005) in their study of rural Haryana, found that majority of landless rural aged were suffering from one or the other health problems and physical disabilities. Bhardwaj (2008) has undertaken a study on "Health and Ageing Among Dhanka and Brahmin of Rajasthan" to evaluate the level of literacy, type of family ,socio -economic status, health problems, old age disease and anthropometric and psychological variation among two populations. Tyagi (2008) found in her study on "SocioHealth Dimensions of aged Population" that dietary habit of elderly staying in the old age homes were more regular as compared to old people living in family set up. The elderly staying within families were reported to be quite involved with the daily house-hold actives and were not able to spare much time for leisure time activities unlike their counterparts staying in old age home. Khandelwal (2012) pointed that disruption of the family support brings loneliness and consequential emotional problems, physical and psychiatric morbidity. Ramathirtham et al. (2012) in their research on "Health Problem of Aged People" found that they were seriously ill. Gender-wise differences were found in the health status of women was found to be poor. Rao et al. (2013) in a study of Health Status of the Rural Aged in Andhra Pradesh, found that health problems tend to increase with advancing age and very often the problems aggravate due to neglect, poor economic status, Social deprivation and inappropriate dietary intake. The above review of literature suggest that although there are number of studies on the aged population in India, but there are some specific socio-cultural features of the population which can only be known while studying the particular society.

\section{Methodology:-}

There are 21 districts in Haryana. We have selected Mohindergarh district randomly with the help of lottery method. Each district has several blocks. Mohindergarh district has six blocks namely: Narnaul, Mohindergarh, Ateli, Nangal Choudhary, Kanina and Satnali. We randomly selected one block i. e. Ateli for our study purpose. In the Ateli block, there are 72 villages. Out of these 72 villages, we randomly selected Ateli Nangal village. The population of the Ateli Nangal is 2235 which includes $700 \mathrm{men}, 540$ women, and 995 children. Village has 335 households. We have decided to take every third household from the list procured from the Panchayat office. Every third household means around 118 households made our sample. Thus, in all we interviewed 86 persons who include males and females of the household. From each household, we made it sure that the person interviewed is the eldest in the family. However, 32 households in our sample did not have any elder member in the family who full fill the condition of 60+ or they were sick and not in a position to participate in our interview process. Total 86 persons are interviewed (male and females) from different households.

\section{Techniques of Data Collection:-}

For the collection of data we prepared interview schedule related to social, psychological, economic and health dimensions of the elderly people. The interview schedule is one of the major techniques of data collection. The interview is a face-to-face interaction between two or more persons. We preferred face to face interview session with our respondents as many of them are illiterate and not in a position to write because of their physiological problem of old age. 


\section{Field of Study:-}

The field of study is Ateli Nangal village. Ateli Nangal is a village in Ateli block in Mohindergarh district of Haryana state. It belongs to Gurgaon division. It is located $17 \mathrm{~km}$ towards west from district headquarters Narnaul. Postal head office is Ateli Mandi. Ateli Nangal is located at 28.1 N 76.28 E. It has an average elevation of 299 metres (980 feet), $348 \mathrm{~km}$ from state capital Chandigarh. Ateli Nangal is surrounded by Rewari district towards east, Mohindergarh district towards north. Behror tehsil (Rajasthan) towards south, Ateli, Narnaul, Mohindergarh are the nearby cities to Ateli Nangal. It is near to the Rajasthan state border. AteliNangal total population in 2011 census is 2235; male 700, female 540, children 995 and voting population is 1235 in 2011 census. The total population of old aged people 172 in 2011 census. Lok Sabha constituency is Bhiwani-Mohindergarh and Vidhan Sabha constituency is Ateli.

\section{Socio-Economic Background of Respondents:-}

Age: Age is a significant variable in the formation of attitudes of an individual. Age plays a decisive role in behavioural patterns of aged persons. Hence, age is an important characteristic of human beings. It does not only refer to physical maturity of man/woman, but also serves as an indication of his/her experience, knowledge and worldly wisdom. The data collected from the aged persons on their age groups have been tabulated and presented in the table 1.

Table 1;- Age-wise distribution of the Respondents.

\begin{tabular}{|l|l|l|}
\hline Age group (In Years) & No. of respondents & Percentage \\
\hline $60-69$ years & 44 & 51.17 \\
\hline $70-79$ years & 20 & 23.25 \\
\hline 80 Years and above & 22 & 25.58 \\
\hline Total & 86 & 100.00 \\
\hline
\end{tabular}

The table- 1 reveals age of the respondents. It shows that 44 (51.17 per cent) respondents belonged to the age group of 60-69 years, 20 ( 23.25 per cent) respondents belonged to the age group of $70-79$ years, and 22 ( 25.58 per cent) belonged to the age group of 80 years and above. Majority of the respondents belonged to the age group of 60-69 years.

Sex:- In order to find out whether there is any difference between old man and woman in our sample in the matter of health the data were analysed in table 2 .

Table 2:- Sex-wise Distribution of the Respondent.

\begin{tabular}{|l|l|l|}
\hline Sex-Category & No. of Respondents & Percentage \\
\hline Man & 49 & 56.98 \\
\hline Woman & 37 & 43.02 \\
\hline Total & 86 & 100.00 \\
\hline
\end{tabular}

The table- 2 depicts sex-wise distribution of the respondents. It shows that 49 (56.98 per cent) respondents were man and 37 (43.02 per cent) were woman. Majority of the respondents were man.

Caste:- Indian society is divided in various caste categories where the status of an individual depends on the position in the caste hierarchy. A person's birth in a particular caste defines his/her other positions in the society.

Table 3:- Caste-wise Distribution of the Respondents.

\begin{tabular}{|l|l|l|}
\hline Caste-Category & No. of respondents & Percentage \\
\hline Ahir & 50 & 58.14 \\
\hline Chamar & 19 & 22.09 \\
\hline Khati & 11 & 12.79 \\
\hline Brahmin & 06 & 6.98 \\
\hline Total & 86 & 100.00 \\
\hline
\end{tabular}

Table- 3 shows the caste-wise distribution of the respondents. It depicts that 50 (58.14 per cent) respondents were from Ahir caste which falls in the backward caste category, 19(22.09 per cent) respondents were Chamar which falls in the scheduled caste category, 11(12.79 per cent) were Khati (backward case) and only 6(6.98 per cent) were Brahmin. So majority of the respondents were from Ahir caste. 


\section{Educational Background:-}

Education plays a crucial role in one's personality development and career building. Education is supposed to play an important role in opinion making and guiding action. Education facilitates the development of a progressive attitude in individuals towards social and economic problems. Education is one of the basic indices of socioeconomic status and affects the social behaviour of a person in a significant way.

Table 4:- Educational level of Respondents.

\begin{tabular}{|l|l|l|}
\hline Educational-Level & No of respondents & Percentage \\
\hline Illiterate & 52 & 60.46 \\
\hline Up to primary level & 11 & 12.79 \\
\hline Metric & 13 & 15.12 \\
\hline Senior Secondary & 07 & 8.14 \\
\hline UG and PG & 03 & 3.49 \\
\hline Total & 86 & 100.00 \\
\hline
\end{tabular}

Table- 4 discusses the educational level of the respondents. It depicts that 52 (60.46 per cent) respondents were illiterate, 11 (12.79 per cent) of them were educated up to primary level, 13 (15.12 per cent) were educated up to metric , 7( 8.14 per cent) were having education of senior secondary and only 3 ( 3.49 per cent) respondents were having higher education. Majority of the respondents were illiterate.

Occupation: Occupational status of the respondents is one of the most important variables in determining their socio-economic character. Thus occupation is not only the source of income but also one of the most important criteria for social ranking in our society.

Table 5:- Occupation of the Respondents.

\begin{tabular}{|l|l|l|}
\hline Occupation & No. of respondents & Percentage \\
\hline Agriculture & 39 & 45.35 \\
\hline Retired Govt. Servant & 14 & 16.28 \\
\hline Petty Business & 10 & 11.63 \\
\hline Manual labour & 07 & 8.14 \\
\hline Other occupation & 16 & 18.60 \\
\hline Total & 86 & 100.00 \\
\hline
\end{tabular}

Table -5 reveals the distribution of the respondents according to their past occupation. It shows that 39 (45.35 per cent) were previously engaged in agricultural activities, 14 (16.28 per cent) were retired government employees, 10 (11.63 per cent) were in petty business work, 7(8.14 per cent) were in manual labour and 16(18.60 per cent) respondents were in other occupation which includes looking after cattle's etc. Majority of the respondents were in agricultural activities.

Marital status:- Marriage is a very important institution in India. In the Hindu society, marriage is supposed to be a religious obligation. The cultural impact of marriage is universal. We asked our respondents regarding their marital status and responses are tabulated in table- 6 .

Table 6:- Marital Status of the Respondents.

\begin{tabular}{|l|l|l|}
\hline Marital status & No. of respondents & Percentage \\
\hline Married & 69 & 80.23 \\
\hline Unmarried & 03 & 3.49 \\
\hline Widower & 4 & 4.64 \\
\hline Widow & 10 & 11.63 \\
\hline Total & 86 & 100.00 \\
\hline
\end{tabular}

Table- 6 points out the distribution of respondents according to their marital status. It clearly shows that $69(80.23$ per cent) respondents were married, 3(3.49 per cent) respondents were unmarried and 10(11.63 per cent) women were widows and 4 (4.64 per cent) men were widower. Majority of the respondents were married.

Family Structure: Family is a universal social institution. Types of family also play an important role in our society. So, it is important to look into the family structure of our data. 
Table 7:- Type of Family of the Respondents.

\begin{tabular}{|l|l|l|}
\hline Types of family & No. of Respondents & Percentage \\
\hline Joint family & 75 & 87.21 \\
\hline Nuclear family & 11 & 12.79 \\
\hline Total & 86 & 100.00 \\
\hline
\end{tabular}

Table- 7 shows the types of the family of the respondents. The data depicts that $75(87.21$ per cent $)$ respondents belonged to the joint family and remaining 11 (12.79 per cent) were from nuclear family. Thus, it concludes that village is still dominated by the joint family structure.

Table 8:- Source of income of the respondents.

\begin{tabular}{|l|l|l|}
\hline Sources & No. of respondents & Percentage \\
\hline Pension & $86^{*}$ & 100.00 \\
\hline Bank interest from their Fix deposits & 08 & 9.30 \\
\hline Monthly money is given by their son & 09 & 10.47 \\
\hline Other sources (agriculture, rent etc.) & 11 & 12.79 \\
\hline Total & 86 & 100.00 \\
\hline
\end{tabular}

*All the respondents are getting some or other form of pension

The table- 8 shows the source of income of respondents. The data depicts that the all the respondents are getting pension in some or other form. Beside that 8 (9.30 per cent) of respondents were earning bank interest from their fixed deposit, 9(10.47 per cent) replied that they are regularly receiving money from their sons and 11 (12.79 per cent) respondent had other sources of income which includes income from house rent, agriculture etc.

\section{Economic Independence:-}

Social status ascribed to individual depends on the economic status he has in society. One's economic position can be best determined by studying about his living conditions. Economic independence is very important for any person. It becomes more in the case of the old as old people are not physically able to earn themselves. Moreover, if the old person happens to be poor it becomes more hardship for him

Table 9:- Economic Independence of Respondents.

\begin{tabular}{|l|l|l|}
\hline Economically independent & No. of respondents & Percentage \\
\hline Yes & 37 & 43.02 \\
\hline No & 49 & 56.98 \\
\hline Total & 86 & 100.00 \\
\hline
\end{tabular}

The table-9 reveals the economic independence of the respondents. However, all the respondents are deriving some or other form of pension but that is not sufficient to become economic independent. Data depicts that the 37 (43.02 per cent) respondents were economically independent and 49(56.98 per cent) respondents were economically dependent on their family members. The study concludes that majority of the respondent were economically dependent.

Economic Status:-

Source of Income: Traditionally economic status has been important determinant of the personality of an individual. In old age, one's income becomes reduced, due to his retirement, due to physical ailments. When we asked our respondents about their source of income, their reply in tabulated form is given

Table 10:-

\begin{tabular}{|l|l|l|}
\hline Sources & No. of respondents & Percentage \\
\hline Pension & $86^{*}$ & 100.00 \\
\hline Bank interest from their Fix deposits & 08 & 9.30 \\
\hline Monthly money is given by their son & 09 & 10.47 \\
\hline Other sources (agriculture, rent etc.) & 11 & 12.79 \\
\hline Total & 86 & 100.00 \\
\hline
\end{tabular}


The table-10 shows the source of income of respondents. The data depicts that the all the respondents are getting pension in some or other form. Beside that 8 (9.30 per cent) of respondents were earning bank interest from their fixed deposit, 9(10.47 per cent) replied that they are regularly receiving money from their sons and 11 (12.79 per cent) respondent had other sources of income which includes income from house rent, agriculture etc.

\section{Spending of Income:-}

Money is any object or record that is generally accepted as payment for goods and services. One can buy things in exchange of money. We wanted to know that on which items the respondents spent the income received by them? Following table present the data about their spending of income.

Table 11:-

\begin{tabular}{|l|l|l|}
\hline Items for spending income & No. of respondents & Percentage \\
\hline Eatables & 15 & 17.44 \\
\hline Health & 32 & 37.21 \\
\hline Spent for grandchildren items & 22 & 25.58 \\
\hline Clothing & 09 & 10.46 \\
\hline Miscellaneous & 08 & 9.30 \\
\hline Total & 86 & 100.00 \\
\hline
\end{tabular}

The table -11 shows the spending of income by the respondent. It shows that the 32 (37.21 per cent) respondents spent their income in health, 22(25.58 per cent) respondents were spending their income for grandchildren, $15(17.44$ per cent) respondents were spending their income on eatable items, 9 (10.46 per cent) respondents spent income on clothing and 8 (9.30 per cent) respondents spent their income on alcohol and bidietc. However, majority of respondents were spending their income on health.

\section{Conclusion:-}

Aging implies psychological and psycho-social changes reflected in general physical weakness, decline in sense perception and mental activity and lessening of social activities and interested. Only 12.79 per cent of respondents live in the nuclear family, this shows that in the rural areas joint family tradition today's also exits. Mostly attitude of family members towards respondents were changed. Majority of economically dependence of the respondents because the reduction or loss of income during old age. Most cares during illness of the respondents were spouse and son/daughter. Regarding age, majority of the respondent belonged to age group between 60-69 years. Regarding occupation, mostly respondent were engaged in agriculture occupation in the past. It further analysed that majority of the respondents were illiterate. $1 / 3$ respondents participated in decision making process, majority of the respondents belonged to marriage issues. . The problem of the old is their economic position, the reduction or loss of income during old age. Pensions, majority of the respondent were receiving old age pension (63.95 per cent).

\section{References:-}

1. Bhardwaj, S. (2008): "Health and Aging among Dhanka and Brahmin of Rajasthan", in R. K. Pathak (eds.), Bio- Social issues in Health, New Delhi: Northan Book Centre, pp. 541-549.

2. Bhardwaj, S. et al. (2006): "Age Related Trend in Morphological Variables a Many Females: A Comparative Study among Dhanka Tribal and Brahmins of Rajasthan”, Indian Anthropologists, 36: 129-139.

3. Census of India (1997): Registrar General and Census Commissioner, New Delhi: Government of India.

4. Census of India (2011), Registrar General and Census Commissioner New Delhi: Government of India.

5. Coleman, J. and Gressey, R. (1986): Social Problem, New York: Harper and Row, pp. 237-238.

6. Nayar, P.K.B. (2000): “The Aging Scenario in Kerala: A Holistic Perspective", Help Age India Research and Development Journal, Vol. 6, No 2, Feb. to May 2000.

7. Pandey, Rajendra (1994): Social Problem in Contemporary India, New Delhi: Ashish Publisher, pp. 261-262.

8. Pappathi, K. (2005): "Psycho-Social Characteristics and Problems of the Rural Aged in Help Age India", Research and Development Journal, Vol. 11, No. 1.

9. Ramathirtham, G. (2012): "Health Problems of Aged People", International Journal of Research in Social Sciences, Vol. 2, Issue 3, August.

10. Ramathirtham, G. and Balamurugan, J. (2012): "Health Problems of Aged People", International Journal of Research in Social Sciences, Volume 2, Issue 3, pp. 140-143. 
11. Rammurti, P.V. (1962): “An Adjustment Inventory for Older People”, Journal of Psychological Researches, VII (3).

12. Rao, et al. (2003): "Health Status of the Rural Aged in Andhra Pradesh; A Sociological Perspective in Help Age India", Research and Development Journal, Volume 9, No. 2.

13. Satyanarayana, K. (2012): Impact of Aging on Health and Economic Status- A Case Study of Visakhapatnam Urban.

14. Singh, C.P. (2005): "Socio-Economic Status and Health Conditions of landless Rural Aged in Haryana in Help Age India", Research and Development Journal, Vol. 11, No. 1.

15. Siva Raju, S. (2002): "Meeting the Needs of the Poor and Excluded in India", Situation and Voices the Older Poor and Excluded in South Africa and India, UNFPA: Population and Development Strategies.

16. Tyagi, R. (2008): "Socio-Health Dimensions of Aged Population", in R. K. Pathak (eds.), Bio- Social Issues in Health, New Delhi: Northern Book Centre, pp. 550-555.

17. Vermani, S. and Darshan, S. (1999): "Factors Affecting the Health of Aged", Aging and Society, The Indian Journal of Gerontology, IX (1-2), 21-36.

18. (http://www.harmonyindia.org/hportal/virtual)

19. .(http://www.eldis.org/fulltext/economic\%20and\%20financial\%20Aging.Pdf).

20. (http://www.igidr.ac.in/pdf/publication/wp-2011-013.pdf). 